\title{
ERCC2 225 I A>C genetic polymorphism was highly correlated with early relapse in high-risk stage II and stage III colorectal cancer patients: A preliminary study
}

\author{
Ming-Yii Huang 1,2,3, Wei-Yu Fang ${ }^{4}$, Su-Chen Lee ${ }^{5}$, Tian-Lu Cheng6, Jaw- \\ Yuan Wang*7,8 and Shiu-Ru Lin*4
}

Address: ${ }^{1}$ Graduate Institute of Medicine, Kaohsiung Medical University, Kaohsiung, Taiwan, ${ }^{2}$ Department of Radiation Oncology, Kaohsiung Medical University Hospital, Kaohsiung, Taiwan, ${ }^{3}$ Department of Radiation Oncology, Faculty of Medicine, College of Medicine, Kaohsiung Medical University, Kaohsiung, Taiwan, ${ }^{4}$ Graduate Institute of Medical Genetics, Kaohsiung Medical University, Kaohsiung, Taiwan, ${ }^{5}$ Laboratory Medicine, Kaohsiung Medical University Hospital, Kaohsiung, Taiwan, ${ }^{6}$ Faculty of Biomedical Science and Environmental Biology, Kaohsiung Medical University, Kaohsiung, Taiwan, ${ }^{7}$ Division of Gastrointestinal and General Surgery, Department of Surgery, Kaohsiung Medical University Hospital, Kaohsiung, Taiwan and ${ }^{8}$ Department of Surgery, Faculty of Medicine, College of Medicine, Kaohsiung Medical University, Kaohsiung, Taiwan

Email: Ming-Yii Huang - miyihu@kmu.edu.tw; Wei-Yu Fang - james19840813@hotmail.com; Su-Chen Lee - sclee@kmu.edu.tw; TianLu Cheng - alucheng5024@yahoo.com.tw; Jaw-Yuan Wang* - cy614112@ms14.hinet.net; Shiu-Ru Lin* - srlin@ms2.hinet.net

* Corresponding authors

Published: 12 February 2008

BMC Cancer 2008, 8:50 doi:10.1 186/147/-2407-8-50
Received: 14 September 2007

Accepted: 12 February 2008

This article is available from: http://www.biomedcentral.com/I47I-2407/8/50

(c) 2008 Huang et al; licensee BioMed Central Ltd.

This is an Open Access article distributed under the terms of the Creative Commons Attribution License (http://creativecommons.org/licenses/by/2.0), which permits unrestricted use, distribution, and reproduction in any medium, provided the original work is properly cited.

\begin{abstract}
Background: Early relapse in colorectal cancer (CRC) patients is attributed mainly to the higher malignant entity (such as an unfavorable genotype, deeper tumor invasion, lymph node metastasis and advance cancer stage) and poor response to chemotherapy. Several investigations have demonstrated that genetic polymorphisms in drug-targeted genes, metabolizing enzymes, and DNA-repairing enzymes are all strongly correlated with inter-individual differences in the efficacy and toxicity of many treatment regimens. This preliminary study attempts to identify the correlation between genetic polymorphisms and clinicopathological features of CRC, and evaluates the relationship between genetic polymorphisms and chemotherapeutic susceptibility of Taiwanese CRC patients. To our knowledge, this study discusses, for the first time, early cancer relapse and its indication by multiple genes.
\end{abstract}

Methods: Six gene polymorphisms functional in drug-metabolism - GSTPI lle I05Val, ABCBI lle I I45Ile, MTHFR Ala222Val, TYMS double (2R) or triple (3R) tandem repeat - and DNA-repair genes - ERCC2 Lys75IGln and XRCCI Arg399Gln - were assessed in 20 I CRC patients using a polymerase chain reaction-restriction fragment-length polymorphism (PCR-RFLP) technique and DNA sequencing. Patients were diagnosed as either high-risk stage II (T2 and 3 NO MO) or III (any T NI and 2 M0) and were administered adjuvant chemotherapy regimens that included 5 -fluorouracil (5FU) and leucovorin (LV). The correlations between genetic polymorphisms and patient clinicopathological features and relapses were investigated.

Results: In this study, the distributions of GSTPI $(P=0.003), A B C B I(P=0.00 I)$, TYMS $(P<0.000 \mathrm{I}), E R C C 2(P<0.000 \mathrm{I})$ and $X R C C I(P=0.006)$ genotypes in the Asian population, with the exception of MTHFR $(P=0.08 \mathrm{I})$, differed significantly from their distributions in a Caucasian population. However, the unfavorable genotype ERCC2 $225 \mathrm{I} A>C(P=0.006)$, tumor invasion depth $(P=0.025)$, lymph node metastasis $(P=0.0 \mathrm{II})$ and cancer stage $(P=0.008)$ were significantly correlated with early relapse. Patients carrying the ERCC2 225 IAC or225 ICC genotypes had a significantly increased risk of early relapse (OR $=3.294,95 \%$ $\mathrm{Cl}$, I.272-8.532).

Conclusion: We suggest that ERCC2 225 IA $>C$ alleles may be genetic predictors of early CRC relapse. 


\section{Background}

The primary treatment for colorectal cancer (CRC) is resection of the primary tumor. After surgery, patients are frequently administered adjuvant chemotherapy to eliminate cancer cells that may have metastasized [1]. Despite chemotherapy, CRC remains the third major cause of cancer-related death in Taiwan, accounting for $>3,000$ deaths per year [2]. The overall five-year survival is $50-60 \%$ in European countries [3], a result similar to that in Taiwan [4]. The primary cause of death is distant and locoregional relapses. Notably, CRC relapse is strongly correlated with chemotherapeutic drug response $[1,5,6]$.

Genetic polymorphisms in drug-targeted genes [7,8], metabolizing enzymes [9], and DNA-repairing enzymes [10] have been linked to inter-individual differences in the efficacy and toxicity of numerous drugs. Several studies have investigated various gene expressions and chemotherapeutic drug responses of cancers. For instance, a polymorphic 28-bp tandem double repeat polymorphism in the regulatory region of the TYMS gene is correlated with a better response to 5 -fluorouracil ( $5 \mathrm{FU}$ ) chemotherapy than the triple repeat in the polymorphism [11]. A common polymorphism in the MTHFR gene $(677 \mathrm{C}>\mathrm{T}$; Ala222Val) increases the efficacy of fluoropyrimidinebased chemotherapy [12]. In Caucasian patients with advanced CRC who are treated with oxaliplatin, $5 \mathrm{FU}$ and leucovorin (LV), ERCC1 $118 \mathrm{~T} / \mathrm{T}$, XRCC1 (Arg - > Gln substitution in exon 10), ERCC2 751AC, and ERCC2 751CC genotypes are independently associated with poor progression-free survival and short-term survival $[13,14]$. Glutathione S-transferases (GSTs) participate in the detoxification of platinum compounds and are important mediators of intrinsic and acquired resistance to oxaliplatin [8].

Advanced CRC is one of the most chemotherapy-resistant human malignancies. The cytotoxic agent with the most consistent antitumor activity is $5 \mathrm{FU}$. However, significant variability in drug response can occur among cancer patients treated with the same medications [15]. Elevated levels of thymidylate synthase (TS) are correlated with resistance to $5 \mathrm{FU}$ and a poor clinical outcome [16-19].

Conventional regimens for treating cancer patients with chemotherapy do not account for interpatient variability in the expression of particular target genes. Such variability results in unpredictable tumor responses and host toxicity. This hospital-based study investigates the role of multiple genetic polymorphisms of six metabolizing and DNA-repair genes (GSTP1, Glutathione S-transferase P1; $A B C B 1$, multidrug resistance $1 ;$ MTHFR, methylenetetrahydrofolate reductase; TYMS, thymidylate synthase; ERCC2, excision repair cross-complementing rodent repair deficiency, complementation group 2; XRCC1, X- ray cross-complementing 1 ) in literature, genomic databases, and the Medline database [10-12,20-23]. The correlations between single nucleotide polymorphisms of the six candidate genes and clinicopathological features of 201 Taiwanese CRC patients, in addition to the relationship between genetic variants and post-therapy early relapse, were also analyzed to elucidate the roles of genotypes of these six genes as predictors of response of CRC patients following $5 \mathrm{FU} / \mathrm{LV}$ chemotherapy. Furthermore, this study reviewed current literature regarding the distribution of these six candidate genes and their genotypes in CRC patients of different ethnic groups, and compared differences between Taiwanese CRC patients and those of other races.

This is the first investigation of clinical outcome using multiple chemotherapeutic drug-related genetic polymorphisms for Taiwanese patients with advanced CRC. The ability to predict with a high degree of accuracy which patients are likely to respond to treatment and those who are unlikely to respond will significantly influence the design of new treatment regimens.

\section{Methods \\ Patients and specimens}

Enrolled in this prospective study were 201 Taiwanese high-risk International Union Against Cancer (UICC) stage II and stage III CRC patients (median age, $62.09 \pm$ 12.67 years) who were admitted to the Department of Surgery at Kaohsiung Medical University Hospital for elective surgery. Patients with other malignant diseases in their medical history were excluded. All 201 patients underwent radical resection for a primary lesion. Radical resection was defined as any gross residual tumor that did not remain in the surgical bed, and the surgical resection margin is pathologically negative for tumor invasion. All patients were diagnosed as either high-risk stage II (T2 and 3 NO M0) or III (any T N1 and $2 \mathrm{M0}$ ). Patients with risk factors for relapse (tumor poorly differentiated, tumor perforation, number of lymph nodes examined $<12$ or lymphatic/vascular invasion) were considered high-risk stage II cases. Written informed consent was obtained from all subjects and/or guardians for use of their blood samples. The follow-up endpoint was June 2007. Sample acquisition and subsequent use were approved by the institutional review board at the Kaohsiung Medical University Hospital. Patients were administered six 8-week cycles of adjuvant chemotherapy. Each cycle consisted of leucovorin $500 \mathrm{mg} / \mathrm{m}^{2}$ administered as a 2-h infusion and given weekly for six doses, and $5 \mathrm{FU} 500 \mathrm{mg} / \mathrm{m}^{2}$ administered as an intravenous bolus $1 \mathrm{~h}$ after the start of leucovorin infusion and repeated weekly for 6 doses. This cycle was then repeated after a 2-week rest period. Postoperative surveillance consisted of comprised medical history, physical examination, and laboratory studies, including 
assessing serum carcinoembryonic antigen (CEA) levels at 3 -month intervals. Abdominal ultrasonography or computed tomography was performed at 6-month intervals, and chest radiography, bone scans, and total colonoscopy were performed annually. Patients were followed up at 3month intervals for 2 years and at 6-month intervals thereafter. Median follow-up time was 34.2 months (range, 24-40 months). Clinical stage and pathological features of primary tumors were defined according to criteria of the American Joint Commission on Cancer/International Union Against Cancer (AJCC/UICC) [24].

Development of new post-operative recurrent or metastatic lesions was defined as postoperative relapse. Early relapse was defined as local recurrence (tumor growth restricted to the anastomosis or the region of the primary operation) or distant metastasis (distant metastasis or diffuse peritoneal seeding) within 1 year following radical resection.

\section{DNA extraction}

Constitutional gene polymorphisms were analyzed via DNA extraction from $4 \mathrm{ml}$ peripheral blood using a PUREGENE $^{\circledast}$ DNA Isolation Kit (Gentra Systems, Inc., Minneapolis, MN, USA).

\section{PCR-RFLP}

All genomic DNA from patients were examined using the polymerase chain reaction-restriction fragment length polymorphism (PCR-RFLP) approach to determine the genotypes of GSTP1, ABCB1, MTHFR, TYMS, ERCC2, and XRCC1. Following digestion with suitable restriction enzymes, PCR fragments were separated on a $2.5-3.0 \%$ agarose gel and visualized after ethidium bromide staining. This study also utilized the automated sequencing approach to confirm PCR-RFLP results (Figs. 1, 2, 3, 4). All primers utilized in this study were designed by using Primer3 freeware [25]. Table 1 presents the primer sequences and restriction enzymes. The PCR reaction volume was $40 \mu \mathrm{L}$. The PCR conditions, for the GSTP1 poly- morphism were as follows: $95^{\circ} \mathrm{C}$ for $5 \mathrm{~min}, 35$ cycles at $95^{\circ} \mathrm{C}$ for $30 \mathrm{~s}$, annealing at $65^{\circ} \mathrm{C}$ for $10 \mathrm{~s}$, and $72^{\circ} \mathrm{C}$ for $25 \mathrm{~s}$. A 433-bp product was amplified following digestion with BsmAI. Digestion generated fragments of 329 and $104 \mathrm{bp}$ for the A allele, and fragments of 222, 107, and 104 bp for the Gallele. The PCR conditions for the ABCB1 polymorphism were as follows: $95^{\circ} \mathrm{C}$ for $5 \mathrm{~min}, 35$ cycles at $95^{\circ} \mathrm{C}$ for $30 \mathrm{~s}$, annealing at $58^{\circ} \mathrm{C}$ for $15 \mathrm{~s}$, and $72^{\circ} \mathrm{C}$ for 20 s. A 244-bp product was amplified following digestion with DpnII. Digestion generated fragments of 172 and 72 bp for the C allele, and a 244-bp fragment for the T allele. The PCR conditions for the MTHFR polymorphism were as follows: $95^{\circ} \mathrm{C}$ for $5 \mathrm{~min}, 35$ cycles at $95^{\circ} \mathrm{C}$ for $30 \mathrm{~s}$, annealing at $70^{\circ} \mathrm{C}$ for $20 \mathrm{~s}$, and $72^{\circ} \mathrm{C}$ for $25 \mathrm{~s}$. A 400-bp product was amplified following digestion with Hinfl. Digestion produced a 400-bp fragment for the C allele, and 318 and $82 \mathrm{bp}$ fragments for the T allele. The PCR conditions for the TYMS polymorphism were as follows: $95^{\circ} \mathrm{C}$ for $5 \mathrm{~min}, 35$ cycles at $95^{\circ} \mathrm{C}$ for $30 \mathrm{~s}$, and $72^{\circ} \mathrm{C}$ for $35 \mathrm{~s}$. A 240 - and 212-bp product was amplified for the $3 \mathrm{R}$ allele and $2 \mathrm{R}$ allele, respectively. The PCR conditions for the ERCC2 polymorphism were as follows: $95^{\circ} \mathrm{C}$ for 5 min, 35 cycles at $95^{\circ} \mathrm{C}$ for $30 \mathrm{~s}$, annealing at $64^{\circ} \mathrm{C}$ for 10 s, and $72^{\circ} \mathrm{C}$ for $20 \mathrm{~s}$. A 149 -bp product was amplified following digestion with PstI. Digestion generated 143- and 6-bp fragments for the A allele, and fragments of 80, 63, and $6 \mathrm{bp}$ for the $\mathrm{C}$ allele. The PCR conditions for the XRCC1 polymorphism were as follows: $95^{\circ} \mathrm{C}$ for $5 \mathrm{~min}$, 35 cycles at $95^{\circ} \mathrm{C}$ for $30 \mathrm{~s}$, annealing at $62^{\circ} \mathrm{C}$ for $20 \mathrm{~s}$, and $72^{\circ} \mathrm{C}$ for $20 \mathrm{~s}$. A 208-bp product was amplified following digestion with MspI. Digestion produced 156- and 52-bp fragments for the G allele, and a 208-bp fragment for the A allele.

\section{Statistical analysis}

All data were analyzed using the Statistical Package for the Social Sciences Version 12.0 (SPSS, Inc., Chicago, IL, USA). The correlation between a polymorphism and relapse status was assessed using the relative risk ratio and a 95\% confidence interval (CI). This is an exploratory and

Table I: Characteristics of the studied polymorphisms with primer sequences and restriction enzymes

\begin{tabular}{|c|c|c|c|}
\hline Gene & Primer sequences & Restriction enzyme & Polymorphism \\
\hline GSTPI & $\begin{array}{l}\text { [F]:G5'-GTAGTTTGCCCAAGGTCAAG-3' } \\
{[\text { R]:G5'-AGCCACCTGAGGGGTAAG-3' }}\end{array}$ & BsmAl & Ilel05Val $(3 \mid 3 A>G)$ \\
\hline$A B C B I$ & $\begin{array}{l}\text { [F]:G5'-GATCTGTGAACTCTTGTTTTC-3' } \\
{[\mathrm{R}]: G 5 \text { '-GAAGAGAGACTTACATTAGGC-3' }}\end{array}$ & Dpnll & Ilell45lle (3435C>T) \\
\hline MTHFR & $\begin{array}{l}\text { [F]:G5'-CTTGAACAGGTGGAGGCCAGC-3' } \\
{[\mathrm{R}]: G 5 \text { '-AGGACGGTGCGGTGAGAGTG-3' }}\end{array}$ & Hinfl & Ala222Val $(677 C>T)$ \\
\hline TYMS & $\begin{array}{l}\text { [F]:G5'-GACCCCGCCGAGCAGGAAGA-3' } \\
{[\text { R]:G5'-GTGCCCGTGCGGTCGTCCTT-3' }}\end{array}$ & - & 28-bp repeat (5'-UTR) \\
\hline ERCC2 & $\begin{array}{l}\text { [F]:G5'-TCTGCAGGAGGATCAGCTG-3' } \\
{[\mathrm{R}]: G 5 \text { '-GCAAGACTCAGGAGTCAC-3' }}\end{array}$ & Pstl & Lys75IGln $(225 \mid A>C)$ \\
\hline$X R C C I$ & $\begin{array}{l}\text { [F]:G5'-TTGTGCTTTCTCTGTGTCCA-3' } \\
{[\mathrm{R}]: \text { G5'-TCCTCCAGCCTTTTCTGATA-3' }}\end{array}$ & Mspl & 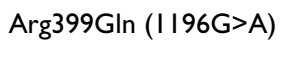 \\
\hline
\end{tabular}



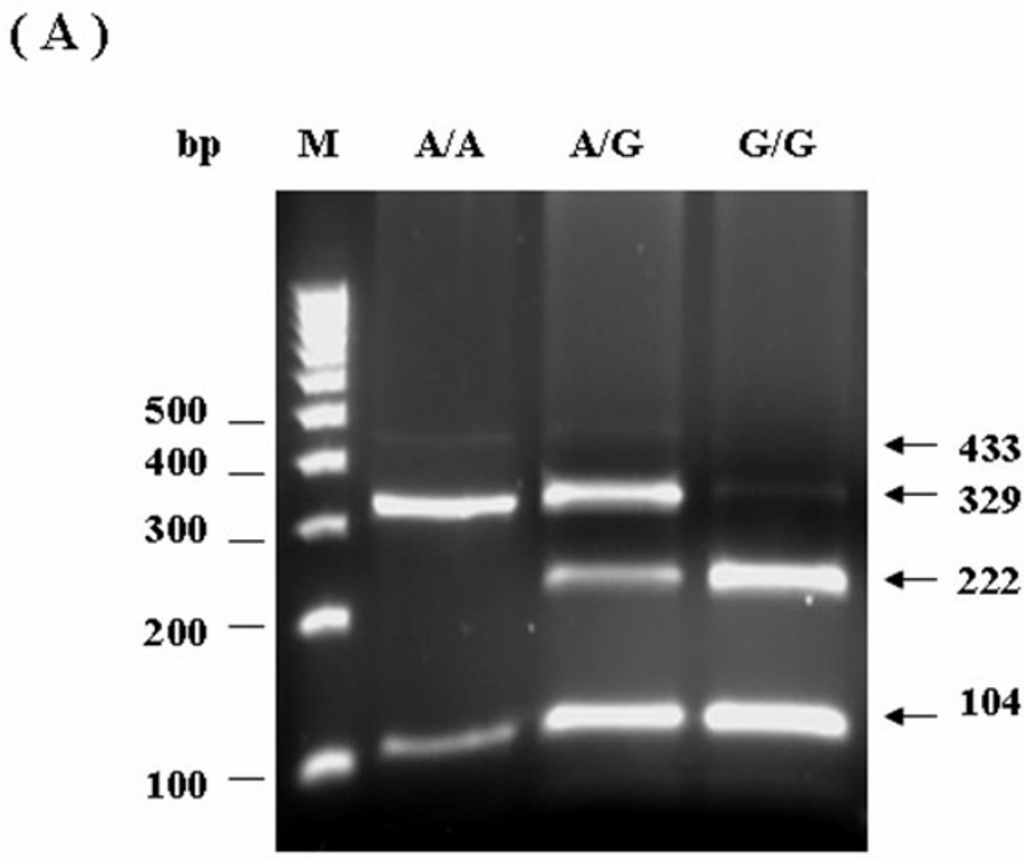

(B)

(C)
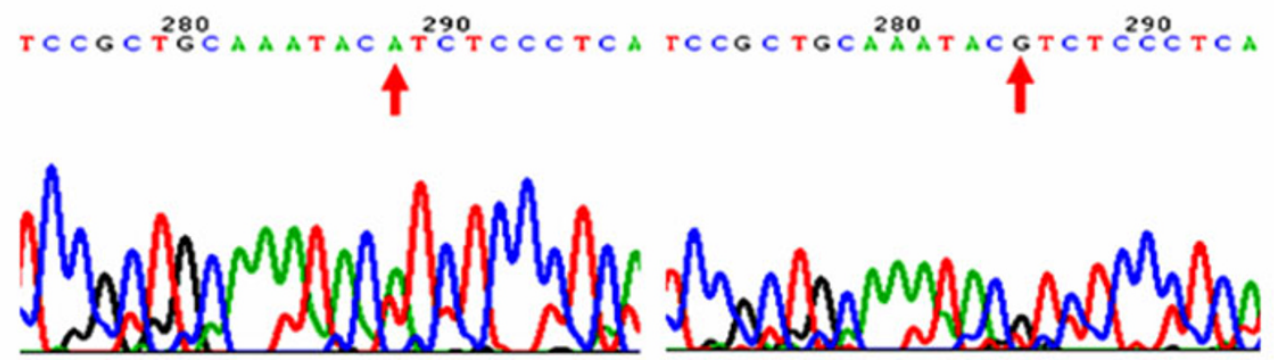

\section{Figure I}

PCR-RFLP analysis and automated sequencing of GSTPI A3 I 3G. Figures IA-C present PCR-RFLP analysis results for GSTPI single nucleotide polymorphisms. The GSTPI exon5 A3 I3G was restricted by BsmAl. Digestion resulted in 329 and I04 bp fragments for the $A$ allele, and 222, I07, and 104 bp fragments for the $G$ allele (Fig. IA: The RFLP of GSTPI results. Fig. IB: Picture of GSTPI 3I3AA sequences. Fig. IC: Picture of GSTPI 3I3GG sequences)

hypothesis-generating study. To clarify the clinical significance of these combined genotypes as predictors of postoperative relapse, a multivariate adjustment was performed by logistic regression analysis. The two-sided Pearson $\chi^{2}$ test was applied to assess the differences in distributions of genotypes between different races. A value of $P<0.05$ was considered statistically significant.

\section{Results}

\section{Patient characteristics}

In total, 201 patients were enrolled. Of these, 118 were male (58.7\%) and 83 were female (41.3\%). Thirty-three patients (16.4\%) were aged : $\leqq 50$ years and $120(59.7 \%)$ were $>60$ years (range, 33-75 years). Thirty cases $(14.9 \%)$ developed early relapse, either local recurrence or distant metastasis, during follow-up. Primary tumor location for 146 cases $(72.6 \%)$ was the colon and $55(27.4 \%)$ was the rectum. In total, 105 cases (52.2\%) were UICC stage II, and 96 cases $(47.8 \%)$ were UICC stage III. Table 2 lists the other clinicopathological characteristics of patients and tumors. 
(A)

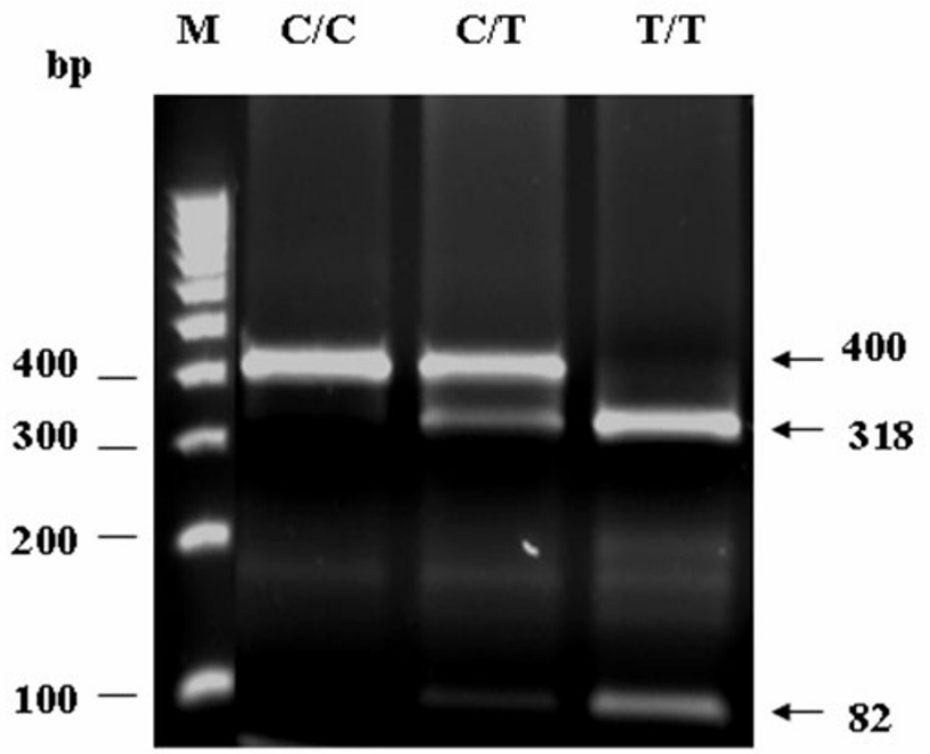

( B )

(C)
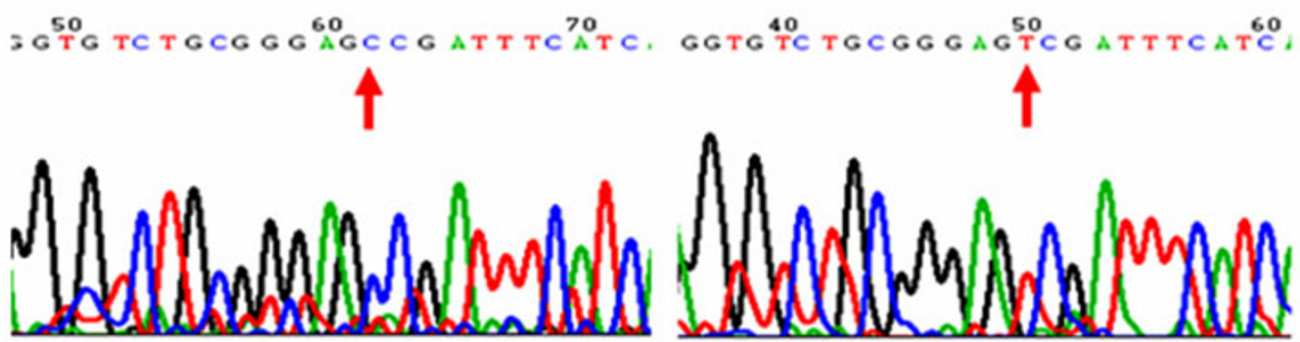

Figure 2

PCR-RFLP analysis and automated sequencing of MTHFR C667T. Figures 2A-C present PCR-RFLP analysis results for MTHFR single nucleotide polymorphisms. Notably, MTHFR was restricted by Hinfl. Digestion resulted in a 400-bp fragment for the $C$ allele, and 318 and 82 bp fragments for the T allele. (Fig. 2A: Results for RFLP of MTHFR. Fig. 2B: Picture of MTHFR $677 \mathrm{CC}$ sequences. Fig. 2C: Picture of MTHFR 677TT sequences)

\section{Correlation between early relapse and clinicopathological data}

No statistical correlations existed between early relapse status and sex, age, tumor size, tumor location and histology $(P>0.05$; Table 2$)$. However, depth of tumor invasion, lymph node metastasis and cancer stage were significantly related to early relapse $(P<0.05)$. Risk of early relapse was higher in $\mathrm{T} 3+\mathrm{T} 4$ that had a deeper invasion than did T2 (OR, 1.205; 95\% CI, 1.127-1.289; $P=$ $0.025)$. Stage III patients had a higher early relapse rate than stage II patients (OR, 2.897; 95\% CI, 1.243-6.381; P $=0.011)$, and early relapse was higher in cases with lymph node metastasis than those with no lymph node metastasis (OR, 2.987; 95\% CI, 1.293-6.899; $P=0.008)$.

\section{Comparison of genotype distributions between Taiwanese CRC patients and those of other races}

To compare the genotypes of Taiwanese CRC patients with those of other races (Table 3 ), this study compared the distribution of gene polymorphisms, such as GSTP1 313A >G (AA, AG, GG), ABCB1 3435C>T (CC, CT, TT), MTHFR 677C>T (CC, CT, TT), TYMS tandem repeat (3R3R, 2R3R, 2R2R), ERCC2 2251A>C (AA, AC, CC) and XRCC1 $1196 \mathrm{G}>\mathrm{A}(\mathrm{GG}, \mathrm{GA}, \mathrm{AA})$, in various races, races - 


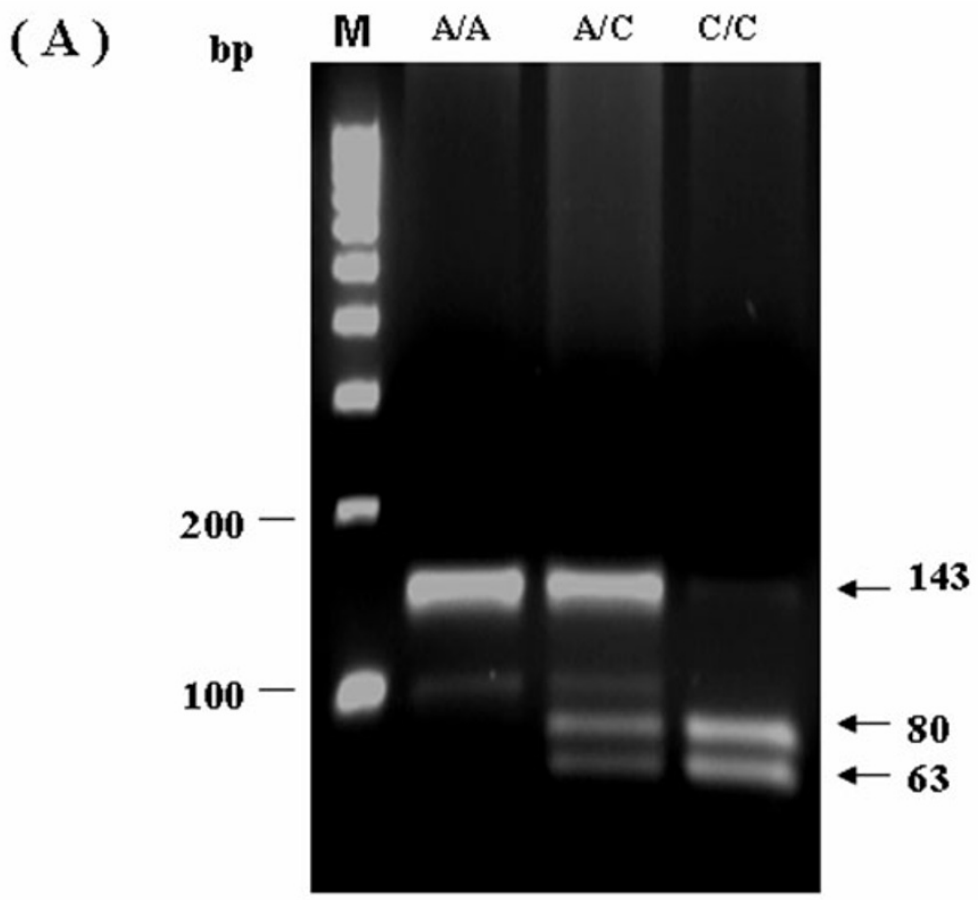

\section{( B )}

( C)

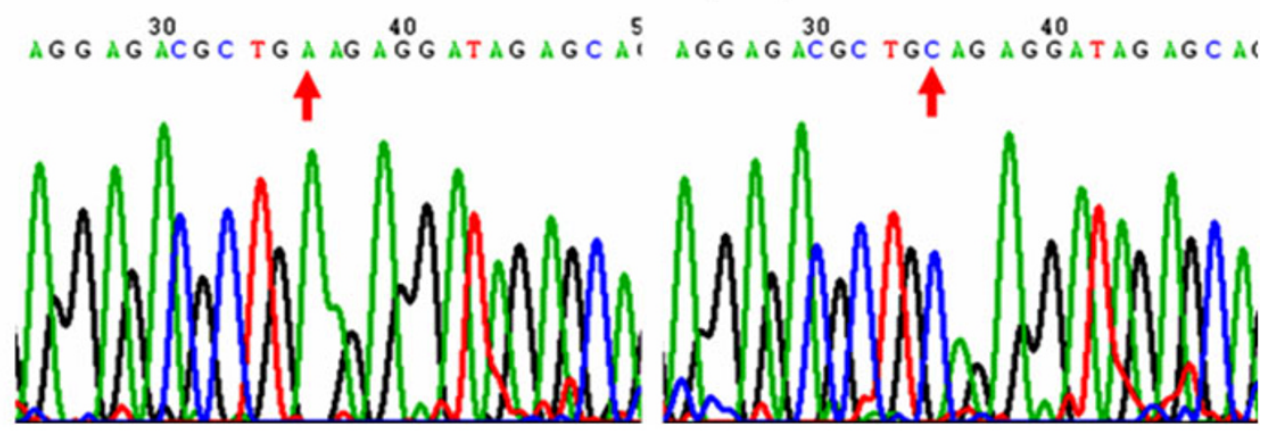

\section{Figure 3}

PCR-RFLP analysis and automated sequencing of ERCC2 A225 I C. Figures 3A-C present PCR-RFLP analysis results for ERCC2 single nucleotide polymorphisms. Notably, ERCC2 was restricted by Mspl. Digestion resulted in I43 and 6 bp fragments for the $A$ allele, and 80, 63, and 6 bp fragments for the $C$ allele. (Fig. 3A: Result for RFLP of ERCC2. Fig. 3B: Picture of ERCC2 225IAA sequences. Fig. 3C: Picture of ERCC2 225ICC sequences)

Caucasian, Japanese, Korean, Chinese, and Taiwanese. This study also included our findings from a literature review.

For GSTP1, 129 (64.2\%) were AA, 66 (32.8\%) were AG and $6(3.0 \%)$ were GG genotype carriers, as compared with Caucasians [26] (AA, 42\%; AG, 47.4\%; GG, 10.6\%) and Taiwanese [27] (AA, 67.9\%; AG, 28.7\%; GG, 3.4\%). The distribution of GSTP1 313A>G genotypes in our data differed significantly from that of Caucasian patients $(P=$
0.003); however, no significant differences existed when compared with previous Taiwanese studies $(P=0.827)$.

For $A B C B 1,70$ (34.8\%) were CC, 104 (51.8\%) were CT and $27(13.4 \%)$ were TT genotype carriers, as compared with Caucasians [28] (CC, 22.3\%; CT, 44\%; TT, 33.7\%), Japanese [29] (CC, 29.2\%; CT, 58.3\%; TT, 12.5\%) and Korean [30] (CC, 28.8\%; CT, 56.8\%; TT, 14.4\%). The distribution of $A B C B 13435 \mathrm{C}>\mathrm{T}$ genotypes was significantly different from that in Caucasians $(P=0.001)$ and not sig- 


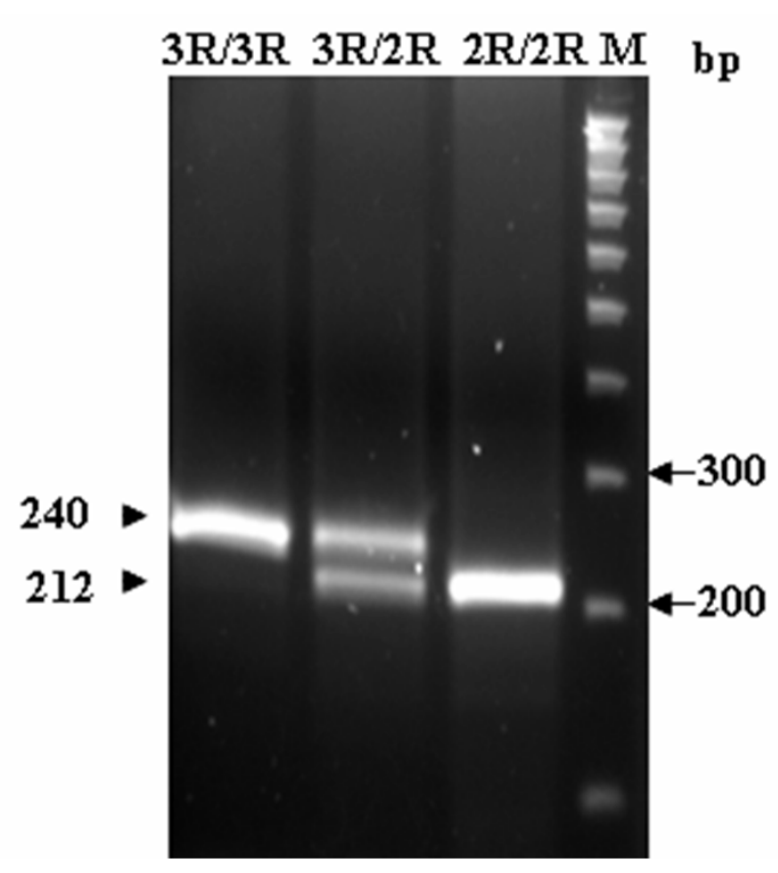

\section{Figure 4}

PCR-RFLP analysis of TYMS repeat polymorphisms. Figure 4 presents PCR-RFLP analysis results for TYMS repeat polymorphisms. A 240-bp product was amplified for the $3 R$ allele and a 212-bp product was amplified for the $2 R$ allele.

nificantly different from that in Japanese $(P=0.641)$, and Korean populations $(P=0.661)$.

For MTHFR, 122 (60.7\%) were CC, 72 (35.8\%) were CT and 7 (3.5\%) were TT genotype carriers, as compared with Caucasians [31] (CC, 46\%; CT, 45\%; TT, 9\%), Japanese [32] (CC, 39.4\%; CT, 48.2\%; TT, 12.4\%), and Korean [33] (CC, 35.4\%; CT, 50.2\%; TT, 14.4\%) populations. Significantly different distributions of MTHFR 677C>T (CC, CT, $T T)$ genotypes existed when our data was compared with Japanese $(P=0.005)$ or Korean data $(P=0.001)$, and it does not significantly different from Caucasian data $(P=$ $0.081)$.

For TYMS, 135 (67.2\%) were 3R/3R, 59 (29.3\%) were 2R/ $3 \mathrm{R}$, and $7(3.5 \%)$ were $2 \mathrm{R} / 2 \mathrm{R}$ genotype carriers, as compared with Caucasians $(3 \mathrm{R} / 3 \mathrm{R}, 32 \% ; 3 \mathrm{R} / 2 \mathrm{R}, 50 \% ; 2 \mathrm{R} / 2 \mathrm{R}$, $18 \%)$, Japanese [34] (3R/3R, 69\%; 3R/2R, 27\%; 2R/2R, $4 \%)$, and Chinese [35] (3R/3R, 67\%; 3R/2R, 31\%; 2R/2R, $2 \%)$ populations. The highest expression of TYMS 3R/3R in this study of Taiwanese patients was similar to that of Japanese $(P=0.951)$ and Chinese populations $(P=$ $0.693)$, but different from that of the Caucasian population [36] $(P<0.0001)$.
For ERCC2, 176 (87.6\%) were AA, 24 (11.9\%) were AC, and $1(0.5 \%)$ were CC genotype carriers, as compared with Caucasians [37] (AA, 25\%; AC, 61\%; CC, 14\%) and Taiwanese [38] (AA, 84\%; AC, 15.6\%; CC, 0.4\%) populations. The highest expression of ERCC2 AA in this study was similar to that in a previous study [38] $(P=0.436)$ and different from that of a Caucasian population $(P<$ 0.0001). Caucasian CRC cancer patients presented with ERCC2 AC as the most common polymorphism genotype. In this study and another previous Taiwanese studies, ERCC2 2251A >C AA was more common than AC and CC, while another study indicated that ERCC2 2251A>C $\mathrm{AC}$ was the most frequent genotype.

For XRCC1, $124(61.7 \%)$ were GG, 64 (31.8\%) were GA and $13(6.5 \%)$ were AA genotype carriers, as compared with Caucasian [37] (GG, 39\%; GA, 52\%; AA, 9\%), Korean [39] (GG, 53.6\%; GA, 42.1\%; AA, 4.3\%), and Taiwanese [38] (GG, 56.7\%; GA, 36.2\%; AA, 7.1\%) populations. The highest expression of XRCC1 GG in this study was similar to that for Koreans $(P=0.257)$ and other Taiwanese studies $(P=0.802)$, but different from that of the Caucasian population $(P=0.006)$.

\section{Correlation between genetic polymorphisms with clinicopathological data}

This study assessed correlations between genetic polymorphisms and clinicopathological features of 201 Taiwanese CRC patients (Table 4). No statistically significant correlations existed between genotype distributions and sex, age, tumor site or location, depth of tumor invasion, lymph node metastasis, cancer stage, or histology (all $P>0.05$ ).

\section{Correlation between early relapse and genetic polymorphisms}

The correlations between gene polymorphisms (GSTP1 313A>G, ABCB1 3435C>T, MTHFR 667C>T, TYMS double or triple tandem repeats, ERCC2 2251A>C and XRCC1 $1196 \mathrm{G}>\mathrm{A}$ ) and patients with or without early recurrence were examined. Statistical analyses indicate that genotype polymorphisms of ERCC2 were strongly correlated between patients with recurrent and non-recurrent tumors $(P=0.006$; Table 5); however, GSTP1, ABCB1, MTHFR, TYMS, and XRCC1 genotypes polymorphisms were not correlated $(P>0.05$; Table 5). The Taiwanese CRC patients with ERCC2 2251AC and ERCC2 2251CC genotypes have a risk of recurrence 3.294 times greater than that of those with other genotypes $(P=0.01 ; 95 \% \mathrm{CI}$, $1.272-8.532)$.

\section{Discussion}

This is an exploratory and hypothesis-generating study. This study attempted to move beyond single genetic polymorphisms to a more comprehensive investigation that identifies genomic variants and patterns and performed 
Table 2: Correlations between clinicopathological features and recurrence status for $20 \mathrm{I}$ postoperative colorectal cancer patients

\begin{tabular}{|c|c|c|c|c|}
\hline Characteristics & Total cases N (\%) & Early recurrence $\mathrm{N}(\%)$ & Non-early recurrence $\mathrm{N}(\%)$ & $P$ \\
\hline \multicolumn{5}{|l|}{ Gender } \\
\hline Male & II 8 (58.7) & $17(56.7)$ & $101(59.1)$ & 0.806 \\
\hline Female & $83(4 \mid .3)$ & $13(43.3)$ & $70(40.9)$ & \\
\hline \multicolumn{5}{|l|}{ Age (years) } \\
\hline$>60$ & $120(59.7)$ & $23(76.7)$ & $97(56.7)$ & 0.105 \\
\hline $51 \sim 60$ & $48(23.9)$ & $5(16.7)$ & $43(25.1)$ & \\
\hline$\leqq 50$ & $33(16.4)$ & $2(6.6)$ & $31(18.2)$ & \\
\hline \multicolumn{5}{|l|}{ Tumor Size } \\
\hline$<5 \mathrm{~cm}$ & $107(53.2)$ & $16(53.3)$ & 91 (53.2) & 0.991 \\
\hline$\geqq 5 \mathrm{~cm}$ & $94(46.8)$ & $14(46.7)$ & $80(46.8)$ & \\
\hline \multicolumn{5}{|l|}{ Location } \\
\hline Colon & $146(72.6)$ & $22(73.3)$ & $124(72.5)$ & 0.926 \\
\hline Rectum & $55(27.4)$ & $8(27.7)$ & $47(27.5)$ & \\
\hline \multicolumn{5}{|l|}{ Depth of tumor invasion } \\
\hline $\mathrm{T} 2$ & $26(12.9)$ & $0(0)$ & $25(14.6)$ & 0.025 \\
\hline $\mathrm{T} 3+\mathrm{T} 4$ & $175(87.1)$ & $30(100)$ & $146(85.4)$ & \\
\hline \multicolumn{5}{|l|}{ Lymph node metastasis } \\
\hline Negative & $110(54.7)$ & $10(33.3)$ & $100(58.5)$ & 0.011 \\
\hline Positive & $91(45.3)$ & $20(66.7)$ & $7 I(4 I .5)$ & \\
\hline \multicolumn{5}{|l|}{ Stage (UICC) ${ }^{\mathrm{a}}$} \\
\hline II & $105(52.2)$ & $9(30)$ & $96(56.1)$ & 0.008 \\
\hline III & $96(47.8)$ & $21(70)$ & $75(43.9)$ & \\
\hline \multicolumn{5}{|l|}{ Histology } \\
\hline Well + moderately differentiated & $170(84.6)$ & $23(76.7)$ & 147 (86) & 0.193 \\
\hline Poorly differentiated & $31(15.4)$ & $7(23.3)$ & $24(14)$ & \\
\hline
\end{tabular}

aInternational Union Against Cancer

early relapse analysis. This study investigated six functional genomic polymorphisms in genes, which have different enzyme functions, or expressions, and DNA repair by PCR-RFLP assay and cycling sequencing. This is the first comprehensive study to investigate genotype frequencies of six gene polymorphisms in Taiwanese CRC patients. Additionally, this study analyzed the genotypes of 201 Taiwanese CRC patients and demonstrated that genotype distributions have ethnic variations.

In 5FU-related genes, the incidence of the TYMS gene promoter $3 \mathrm{R} / 3 \mathrm{R}$ genotype in the 201 cases in this study is similar to that in Japanese [34] and Chinese [35] populations, and higher than that in Caucasian populations [36]. Neither the TYMS 2R allele nor the TYMS 3R allele is predominant in Caucasians; however, the TYMS 3R allele is predominant in Asian populations. For the MTHFR C677T polymorphism, the incidence of the 677CC genotype in this Taiwanese CRC population was higher than that for Caucasians [31], and Japanese [32], and Korean [33] populations (Table 3 ). Notably, the $C$ allele and $T$ allele frequencies in Caucasian and Asian populations are similar.

This study assessed the ABCB1 3435C $>\mathrm{T}$ of 201 Taiwanese CRC patients. The frequency of the TT genotype in the 201 Taiwanese patients is similar to that in Japanese [29] and
Korean [30] patients, but lower than that in Caucasian populations [28]. The allele frequency of $\mathrm{C}$ and $\mathrm{T}$ did not differ between Caucasians and Asians.

The genotype data for cell detoxification-related gene polymorphism, GSTP1 313A>G, are similar to that for 408 Taiwanese CRC patients in a study by Yen et al. [27]. Caucasian populations have an equal incidence of AA homozygotes and AG heterozygotes [26]; however, the Taiwanese population has more AA homozygotes than AG heterozygotes. The allele frequency of Ile is also more predominant in Taiwanese patients than in Caucasian patients.

Since the genetic polymorphisms of DNA-repair enzymes may influence DNA adduct levels [40-42], the particular degree of DNA repair capacity can be utilized to identify genetically high-risk individuals for human cancers [43]. Resistance to platinum agents has been attributed to increased tolerance to platinum DNA adducts, enhanced DNA repair, or decreased drug accumulation [44]. Proteins of the nucleotide excision repair (NER) pathway, in particular, are believed play a central role in repair of DNA damage caused by platinum compounds. The enzymes related to the DNA repair system, XRCC1 and ERCC2, were similar to those identified in other studies of Taiwanese CRC patients [38]. Although very few studies have 
Table 3: Comparison of genotype and allele frequencies (\%) between Taiwanese colorectal cancer patients and those of other ethnic groups

\begin{tabular}{|c|c|c|c|c|c|c|}
\hline Genotype & Caucasian & Japanese & Korean & Chinese & Taiwanese & Study data \\
\hline GSTPI & Van der Logt ${ }^{26}$ & & & & $Y_{e h}^{27}$ & \\
\hline $\mathrm{AA}$ & 42.0 & - & - & - & 67.9 & 64.2 \\
\hline AG & 47.4 & - & - & - & 28.7 & 32.8 \\
\hline GG & 10.6 & - & - & - & 3.4 & 3.0 \\
\hline A allele & 0.657 & - & - & - & 0.823 & 0.807 \\
\hline G allele & 0.343 & - & - & - & 0.177 & 0.193 \\
\hline$A B C B I$ & Kurzawski28 & Komoto 29 & $B a e^{30}$ & & & \\
\hline $\mathrm{CC}$ & 22.3 & 29.2 & 28.8 & - & - & 34.8 \\
\hline $\mathrm{CT}$ & 44 & 58.3 & 56.8 & - & - & 51.8 \\
\hline TT & 33.7 & 12.5 & 14.4 & - & - & 13.4 \\
\hline $\mathrm{C}$ allele & 0.443 & 0.584 & 0.572 & - & - & 0.607 \\
\hline T allele & 0.557 & 0.416 & 0.428 & - & - & 0.393 \\
\hline MTHFR & Curtin $^{31}$ & $Y i n^{32}$ & $\mathrm{Kim}^{33}$ & & & \\
\hline $\mathrm{CC}$ & 46 & 39.4 & 35.4 & - & - & 60.7 \\
\hline $\mathrm{CT}$ & 45 & 48.2 & 50.2 & - & - & 35.8 \\
\hline TT & 9 & 12.4 & 14.4 & - & - & 3.5 \\
\hline C allele & 0.685 & 0.635 & 0.605 & - & - & 0.786 \\
\hline T allele & 0.315 & 0.365 & 0.395 & - & - & 0.214 \\
\hline TYMS & Chen ${ }^{36}$ & Kawakami34 & & Marsh ${ }^{35}$ & & \\
\hline $3 R / 3 R$ & 32 & 69 & - & 67 & - & 67.2 \\
\hline $2 R / 3 R$ & 50 & 27 & - & 31 & - & 29.3 \\
\hline $2 R / 2 R$ & 18 & 4 & - & 2 & - & 3.5 \\
\hline $3 R$ allele & 0.570 & 0.825 & - & 0.825 & - & 0.818 \\
\hline $2 \mathrm{R}$ allele & 0.430 & 0.175 & - & 0.175 & - & 0.182 \\
\hline ERCC2 & Stoehlmacher ${ }^{37}$ & & & & $Y e h^{38}$ & \\
\hline AA & 25 & - & - & - & 84 & 87.6 \\
\hline$A C$ & 61 & - & - & - & 15.6 & 11.9 \\
\hline $\mathrm{CC}$ & 14 & - & - & - & 0.4 & 0.5 \\
\hline A allele & 0.555 & - & - & - & 0.918 & 0.935 \\
\hline C allele & 0.445 & - & - & - & 0.082 & 0.065 \\
\hline$X R C C I$ & Stoehlmacher ${ }^{37}$ & & Hong 39 & & $Y e h^{38}$ & \\
\hline GG & 39 & - & 53.6 & - & 56.7 & 61.7 \\
\hline GA & 52 & - & 42.1 & - & 36.2 & 31.8 \\
\hline AA & 9 & - & 4.3 & - & 7.1 & 6.5 \\
\hline G allele & 0.650 & - & 0.747 & - & 0.748 & 0.776 \\
\hline A allele & 0.350 & - & 0.253 & - & 0.252 & 0.224 \\
\hline
\end{tabular}

NOTE: author ${ }^{n}$ in this table is designated by a reference number $\left(^{n}\right)$ and the abbreviated name of the first author in the previously paper.

investigated these two polymorphisms in Asian CRC populations, the incidence of XRCC1 G1196A in a Korean population [39] is similar to that in the 201 Taiwanese patients in this study. However, the frequency of the XRCC1 GG homozygous and GA heterozygous patients in Caucasian [37] and Asian populations differ significantly. Moreover, the frequency of the $\mathrm{G}$ allele and A alleles do not differ between Caucasians and Asians. For ERCC2 $2251 \mathrm{~A}>\mathrm{C}$, the genotype and allele frequencies are dissimilar between Taiwanese and Caucasians [37]. Neither the $\mathrm{A}$ allele nor $\mathrm{C}$ allele has been identified as predominant in Caucasians, whereas the A allele is predominant in the Taiwanese (Table 3).

In 2004, Shirao et al. compared the efficacy, toxicities, and pharmacokinetics of an oral regimen consisting of uracil/ tegafur (UFT) and LV between Japanese patients and Caucasian patients in the United States [45]. Although the response rate did not differ (36.4\% for Japanese patients and $34.1 \%$ for patients in the United States), a difference existed in toxicity profile, specifically the incidence of diarrhea $-9 \%$ in the Japanese population and $22 \%$ in the Caucasian population in the United States. Since genotype frequencies were similar between Japanese and Taiwanese populations, we suggest that cancer chemotherapy efficacy, toxicities, and pharmacokinetics would be similar to those for Japanese patients. Consequently, we hypothesize that these polymorphisms screened have the ability to predict toxicity, clinical outcome and survival in Taiwanese CRC patients. This hypothesis and suggestion warrant further investigation. 
Table 4: Correlation between gene polymorphism and clinicopathological properties of 201 postoperative colorectal cancer patients

\begin{tabular}{|c|c|c|c|c|c|c|c|c|c|c|c|c|c|}
\hline \multirow[b]{2}{*}{ Characteristics } & \multirow[b]{2}{*}{ Total cases $(n)$} & \multicolumn{2}{|c|}{ GSTPI } & \multicolumn{2}{|c|}{$A B C B I$} & \multicolumn{2}{|c|}{ MTHFR } & \multicolumn{2}{|l|}{ TYMS } & \multicolumn{2}{|c|}{$E R C C 2$} & \multicolumn{2}{|c|}{$X R C C I$} \\
\hline & & AA & AG or GG & $\mathrm{CC}$ & CT or TT & $\mathrm{CC}$ & $\mathrm{CT}$ or TT & $3 R 3 R$ & $2 R 3 R$ or $2 R 2 R$ & AA & $A C$ or $C C$ & GG & $\mathrm{GA}$ or $\mathrm{AA}$ \\
\hline \multicolumn{14}{|l|}{ Gender } \\
\hline Male & 118 & 73 & 45 & 46 & 72 & 68 & 50 & 79 & 39 & 102 & 16 & 73 & 45 \\
\hline \multirow[t]{2}{*}{ Female } & 83 & 56 & 27 & 24 & 59 & 54 & 29 & 56 & 27 & 74 & 9 & 51 & 32 \\
\hline & & \multicolumn{2}{|c|}{$P=0.414$} & \multicolumn{2}{|c|}{$P=0.140$} & \multicolumn{2}{|c|}{$P=0.228$} & \multicolumn{2}{|r|}{$P=0.938$} & \multicolumn{2}{|c|}{$P=0.566$} & \multicolumn{2}{|c|}{$P=0.952$} \\
\hline \multicolumn{14}{|l|}{ Age (yr) } \\
\hline$>60$ & 120 & 76 & 44 & 39 & 81 & 76 & 44 & 80 & 40 & 102 & 18 & 74 & 46 \\
\hline $51 \sim 60$ & 48 & 28 & 20 & 20 & 28 & 27 & 21 & 32 & 16 & 42 & 6 & 33 & 15 \\
\hline \multirow[t]{2}{*}{$\leq 50$} & 33 & 25 & 8 & II & 22 & 19 & 14 & 23 & 10 & 32 & I & 17 & 16 \\
\hline & & \multicolumn{2}{|c|}{$P=0.293$} & \multicolumn{2}{|c|}{$P=0.520$} & \multicolumn{2}{|c|}{$P=0.643$} & \multicolumn{2}{|r|}{$P=0.944$} & \multicolumn{2}{|c|}{$P=0.182$} & \multicolumn{2}{|c|}{$P=0.293$} \\
\hline \multicolumn{14}{|l|}{ Tumor Size } \\
\hline$<5 \mathrm{~cm}$ & 107 & 67 & 40 & 37 & 70 & 67 & 40 & 72 & 35 & 94 & 13 & 71 & 36 \\
\hline \multirow{2}{*}{$\geq 5 \mathrm{~cm}$} & 94 & 62 & 32 & 33 & 61 & 55 & 39 & 63 & 31 & 82 & 12 & 53 & $4 I$ \\
\hline & & \multicolumn{2}{|c|}{$P=0.622$} & & $=0.938$ & & $=0.552$ & & $P=0.968$ & & $\mathrm{~b}=0.895$ & & $=0.147$ \\
\hline Location & & & & & & & & & & & & & \\
\hline Colon & 146 & 96 & 50 & 52 & 94 & 86 & 60 & 96 & 50 & 127 & 19 & 89 & 57 \\
\hline Rectum & 55 & 33 & 22 & 18 & 37 & 36 & 19 & 39 & 16 & 49 & 6 & 35 & 20 \\
\hline & & & $P=0.448$ & & $=0.70 \mathrm{I}$ & & $=0.397$ & & $P=0.488$ & & $D=0.687$ & & $=0.728$ \\
\hline $\begin{array}{l}\text { Depth of } \\
\text { tumor invasion }\end{array}$ & & & & & & & & & & & & & \\
\hline $\mathrm{T} 2$ & 26 & 19 & 7 & 9 & 17 & 15 & 11 & 17 & 9 & 22 & 4 & 18 & 8 \\
\hline $\mathrm{T} 3+\mathrm{T} 4$ & 175 & 110 & 65 & 61 & 114 & 107 & 68 & 118 & 57 & 154 & 21 & 106 & 69 \\
\hline & & & $P=0.311$ & & $=0.98 \mathrm{I}$ & & $=0.737$ & & $P=0.836$ & & $=0.626$ & & $=0.397$ \\
\hline $\begin{array}{l}\text { Lymph node } \\
\text { metastasis }\end{array}$ & & & & & & & & & & & & & \\
\hline Negative & 110 & 68 & 42 & 41 & 69 & 65 & 45 & 75 & 35 & 95 & 15 & 66 & 44 \\
\hline Positive & 91 & 61 & 30 & 29 & 62 & 57 & 34 & 60 & 31 & 81 & 10 & 58 & 33 \\
\hline & & & $P=0.443$ & & $=0.423$ & & $=0.608$ & & $P=0.736$ & & $0=0.571$ & & $=0.588$ \\
\hline Stage $\mathrm{e}^{\mathrm{a}}$ & & & & & & & & & & & & & \\
\hline II & 105 & 64 & 41 & 41 & 64 & 62 & 43 & 71 & 34 & 91 & 14 & 63 & 42 \\
\hline III & 96 & 65 & 31 & 29 & 67 & 60 & 36 & 64 & 32 & 85 & II & 61 & 35 \\
\hline & & & $P=0.318$ & & $=0.189$ & & $=0.617$ & & $P=0.886$ & & $=0.687$ & & $=0.606$ \\
\hline
\end{tabular}

alnternational Union Against Cancer

Studies focusing on acute relapse risk of CRC and these metabolizing and DNA-repair genes are limited and controversial. In addition to the statistically significant role of early relapse, including depth of tumor invasion $(P=$ $0.025)$, lymph node metastasis $(P=0.011)$, and cancer stage $(P=0.008)$, analytical results in this study indicate ERCC2 2251A>C AC and CC gene polymorphismswere statistically significant in predicting early relapse.

The DNA repair systems play an important role in maintaining genomic integrity and preventing carcinogenesis [46]. At least four pathways for DNA repair operate on specific DNA damage types [47]. Nucleotide excision repair is the primary pathway in humans. The ERCC2 gene plays a dominant role in nucleotide excision repair and basal transcription, both of which are crucial to the elimination of bulky DNA adducts. Furthermore, the ERCC2 protein is essential for nucleotide excision repair activity $[48,49]$. The ERCC2 gene consists of 23 exons at 19q13.3. Several single nucleotide polymorphisms have been identified in the coding part of ERCC2, of which Ile199Met (C/
G), His201Tyr (C/T), Asp312Asn (G/A), and Lys751Gln $(\mathrm{A} / \mathrm{C})$ result in amino acid changes; however, codon Arg156Arg (C/A) and Asp711Asp (C/T) are silent polymorphisms. The functional effect of ERCC2 polymorphisms remains unclear. The polymorphisms at codon 312 and 751 have been analyzed extensively for their potential ability to increase lung cancer risk $[49,50]$. Although an earlier study showed that ERCC2 homozygous variant individuals were at increased risk of adenomatous polyps [51], associations between DNA repair gene polymorphisms and CRC have not been explored extensively. This study suggests that CRC patients who have the ERCC2 2251AC (751Lys/Gln) or 2251CC (751Glu/Gln) genotypes have a significantly increased early relapse risk $(\mathrm{OR}=3.294 ; 95 \% \mathrm{CI}$, $1.272-8.532$ ), and no statistically significant correlation exists between genotype distributions and clinicopathological features (all $P>0.05$ ).

This study examined potential genetic predictors of CRC relapse. A recent study [52] determined that the $\mathrm{C}(\mathrm{Glu})$ 
Table 5: Distribution of gene polymorphisms in $20 \mathrm{I}$ colorectal cancer patients and regarding the status of recurrence after surgery

\begin{tabular}{|c|c|c|c|c|}
\hline Genotype & Total cases N (\%) & Early Recurrence N (\%) & Non-early recurrence $\mathrm{N}(\%)$ & $P$ \\
\hline \multicolumn{5}{|c|}{ GSTPI Ile I05Val (3।3A>G) } \\
\hline AA & $129(64.2)$ & $19(63.4)$ & $110(64.3)$ & 0.990 \\
\hline AG & $66(32.8)$ & $10(33.3)$ & $56(32.7)$ & \\
\hline GG & $6(3.0)$ & I (3.3) & $5(3)$ & \\
\hline \multicolumn{5}{|c|}{$A B C B /$ lle I I 45lle $(3435 C>T)$} \\
\hline $\mathrm{CC}$ & $70(34.8)$ & $10(33.3)$ & $60(35.1)$ & 0.853 \\
\hline CT & $104(51.8)$ & $15(50)$ & $89(52)$ & \\
\hline TT & $27(13.4)$ & $5(16.7)$ & $22(12.9)$ & \\
\hline \multicolumn{5}{|c|}{ MTHFR Ala222Val $(677 \mathrm{C}>\mathrm{T})$} \\
\hline $\mathrm{CC}$ & $122(60.7)$ & $18(60)$ & $104(60.8)$ & 0.994 \\
\hline $\mathrm{CT}$ & $72(35.8)$ & II (36.7) & $61(35.7)$ & \\
\hline TT & $7(3.5)$ & I (3.3) & $6(3.5)$ & \\
\hline \multicolumn{5}{|c|}{ TYMS double (2R) or triple (3R) tandem repeat } \\
\hline $3 R / 3 R$ & $135(67.2)$ & $20(66.7)$ & $115(67.2)$ & 0.492 \\
\hline $2 R / 3 R$ & $59(29.3)$ & $10(33.3)$ & $49(28.7)$ & \\
\hline $2 R / 2 R$ & $7(3.5)$ & $0(0)$ & $7(4 . I)$ & \\
\hline \multicolumn{5}{|c|}{ ERCC2 Lys $75 \mid \mathrm{Gln}(225 \mid \mathrm{A}>C)$} \\
\hline AA & $176(87.6)$ & $22(73.4)$ & $154(90.1)$ & 0.006 \\
\hline$A C$ & $24(I 1.9)$ & $7(23.3)$ & $17(9.9)$ & \\
\hline CC & I (0.5) & $1(3.3)$ & $0(0)$ & \\
\hline \multicolumn{5}{|c|}{$X R C C I \operatorname{Arg} 399 \mathrm{Gln}(\mathrm{I} 196 \mathrm{G}>\mathrm{A})$} \\
\hline GG & $124(61.7)$ & $17(56.7)$ & $107(62.6)$ & 0.654 \\
\hline GA & $64(31.8)$ & $10(33.3)$ & $54(31.6)$ & \\
\hline$A A$ & $13(6.5)$ & $3(10)$ & $10(5.8)$ & \\
\hline
\end{tabular}

allele of the ERCC2 Lys751Gln variant allele marginally increased lung cancer risk $(\mathrm{OR}=3.61, \mathrm{P}=0.04)$ in a Chinese population, and another identified [53] increased risk for squamous cell carcinoma of the head and neck in patients with the Gln/Gln genotype when compared with the Lys/Lys group. Experimental results in this study indicate that the ERCC2 2251A>C AC and CC gene polymorphisms can predict early relapse; these experimental results are in agreement with the risk role of the $\mathrm{C}$ (Glu) allele of ERCC2 Lys751Gln in early relapse. Inherited single nucleotide polymorphisms of DNA repair genes may contribute to variations in DNA repair capacity and susceptibility to cancer. The molecular functional effect of ERCC2 polymorphisms remains unclear. Although some researchers have identified incomplete repair of DNA damage or of aromatic DNA adducts in the presence of ERCC2 variant alleles [42,54-58], we hypothesize that the malignant entity of the C (Glu) allele of ERCC2 Lys751Gln is responsible for poor prognosis of early relapse among CRC patients receiving similar chemotherapeutic regimens in this study. In 2001, Park reported the finding of a significant relationship between clinical response to chemotherapy (combined oxaliplatin and 5FU) and ERCC2 Lys751Gln polymorphisms. Patients with the Gln/Gln genotype had significantly shorter survival or increased relative risk of dying when compared with the Lys/Lys group [10]. These experimental results suggest that ERCC2 2251A>C may indeed be of functional importance in Taiwanese CRC. Aggressive chemotherapy or combined radiotherapy will be considered for patients with this poor prognostic genotype.

\section{Conclusion}

In conclusion, analytical data in this study suggest that the polymorphism ERCC2 A2251C is associated with risk of CRC early relapse in a Taiwanese population. Additionally, this study analyzed six gene polymorphisms associated with the clinical outcome of Taiwanese CRC patients. These genotypic frequencies vary among ethnic groups. Studies with relatively larger sample sizes are needed to elucidate the effects of these polymorphisms on early relapse risk in this population. However, experimental results in this study serve as a basis for large-scale correlational studies on the relevance of these variants in predicting early relapse of CRC in a Taiwanese population.

\section{Abbreviations}

CRC, colorectal cancer; GSTP1, Glutathione S-transferase P1; ABCB1, multidrug resistance $1 ;$ MTHFR, methylenetetrahydrofolate reductase; TYMS, thymidylate synthase; ERCC2, excision repair cross-complementing rodent repair deficiency, complementation group 2; XRCC1, Xray cross-complementing1; PCR-RFLP, polymerase chain reaction restriction fragment length polymorphism.

\section{Competing interests}

The author(s) declare that they have no competing interests. 


\section{Authors' contributions}

MYH analyzed the data and wrote the manuscript. WYF SCL and TLC made substantial contributions in data acquisition, molecular genetic analyses, statistical analyses and data interpretation, and helped in manuscript preparation. JYW and SRL participated in study design and coordination. All authors read and approved the final manuscript.

\section{Acknowledgements}

The authors would like to thank the National Science Council of the Republic of China, Taiwan, for financially supporting this research under Contract No. NSC 94-2745-B-037-008-URD. Ted Knoy is appreciated for his editorial assistance.

\section{References}

I. Chen LT, Whang-Peng J: Current status of clinical studies for colorectal cancer in Taiwan. Clinical colorectal cancer 2004, 4(3): 196-203.

2. Bonetti A, Zaninelli M, Durante E, Fraccon AP, Franceschi T, Pasini F, Zustovich F, Brienza S: Multiple-target chemotherapy (LVmodulated 5-FU bolus and continuous infusion, oxaliplatin, CPT-II) in advanced 5-FU-refractory colorectal cancer: MTD definition and efficacy evaluation. A phase I-II study. Tumori 2006, 92(5):389-395.

3. Coleman MP, Gatta G, Verdecchia A, Esteve J, Sant M, Storm H, Allemani C, Ciccolallo L, Santaquilani M, Berrino F: EUROCARE-3 summary: cancer survival in Europe at the end of the 20th century. Ann Oncol 2003, I4(Suppl 5):vI28-149.

4. Ju JH, Chang SC, Wang HS, Yang SH, Jiang JK, Chen WC, Lin TC, Hung $\mathrm{H}$, Wang FM, Lin JK: Changes in disease pattern and treatment outcome of colorectal cancer: a review of 5,474 cases in 20 years. Int J Colorectal Dis 2007, 22(8):855-862.

5. Gramont A: Adjuvant therapy of stage II and III colon cancer. Semin Oncol 2005, 32(6 Suppl 8): I I- I4.

6. Schippinger W, Samonigg $H$, Schaberl-Moser R, Greil R, Thodtmann R, Tschmelitsch J, Jagoditsch M, Steger GG, Jakesz R, Herbst F, Hofbauer $F$, Rabl H, Wohlmuth $P$, Gnant M, Thaler J: A prospective randomised phase III trial of adjuvant chemotherapy with 5fluorouracil and leucovorin in patients with stage II colon cancer. Br J Cancer 2007, 97(8): 1021-1027.

7. Gebhardt F, Zanker KS, Brandt B: Modulation of epidermal growth factor receptor gene transcription by a polymorphic dinucleotide repeat in intron I. J Biol Chem 1999, 274(19): $13176-13 \mid 80$.

8. Goto S, lida T, Cho S, Oka M, Kohno S, Kondo T: Overexpression of glutathione S-transferase pi enhances the adduct formation of cisplatin with glutathione in human cancer cells. Free Radic Res 1999, 3 I (6):549-558.

9. Ando $Y$, Saka H, Ando M, Sawa T, Muro K, Ueoka H, Yokoyama A, Saitoh S, Shimokata K, Hasegawa Y: Polymorphisms of UDP-glucuronosyltransferase gene and irinotecan toxicity: a pharmacogenetic analysis. Cancer Res 2000, 60(24):6921-6926.

10. Park DJ, Stoehlmacher J, Zhang W, Tsao-Wei DD, Groshen S, Lenz H]: A Xeroderma pigmentosum group D gene polymorphism predicts clinical outcome to platinum-based chemotherapy in patients with advanced colorectal cancer. Cancer Res 200I, 6 I (24):8654-8658.

I I. Pullarkat ST, Stoehlmacher J, Ghaderi V, Xiong YP, Ingles SA, Sherrod A, Warren R, Tsao-Wei D, Groshen S, Lenz HJ: Thymidylate synthase gene polymorphism determines response and toxicity of 5-FU chemotherapy. Pharmacogenomics J 200I, I(I):65-70.

12. Sohn KJ, Croxford R, Yates Z, Lucock M, Kim YI: Effect of the methylenetetrahydrofolate reductase $C 677 \mathrm{~T}$ polymorphism on chemosensitivity of colon and breast cancer cells to 5 fluorouracil and methotrexate. I Natl Cancer Inst 2004, 96(2): I34- I44.

13. Suh KW, Kim JH, Kim do Y, Kim YB, Lee C, Choi S: Which gene is a dominant predictor of response during FOLFOX chemotherapy for the treatment of metastatic colorectal cancer, the MTHFR or XRCCI gene? Ann Surg Oncol 2006, I3(I I): I379-I385.

14. Ruzzo A, Graziano F, Loupakis F, Rulli E, Canestrari E, Santini D, Catalano V, Ficarelli R, Maltese P, Bisonni R, Masi G, Schiavon G, Giordani P, Giustini L, Falcone A, Tonini G, Silva R, Mattioli R, Floriani I, Magnani $M$ : Pharmacogenetic profiling in patients with advanced colorectal cancer treated with first-line FOLFOX-4 chemotherapy. J Clin Oncol 2007, 25( I 0): I247-I254.

15. Blijham GH: Chemotherapy of colorectal cancer. Anticancer Drugs 1991, 2(3):233-245.

16. Johnston PG, Lenz HJ, Leichman CG, Danenberg KD, Allegra CJ, Danenberg PV, Leichman L: Thymidylate synthase gene and protein expression correlate and are associated with response to 5-fluorouracil in human colorectal and gastric tumors. Cancer Res 1995, 55(7):|407-|4|2.

17. Leichman L, Lenz HJ, Leichman CG, Groshen S, Danenberg K, Baranda J, Spears CP, Boswell W, Silberman H, Ortega A, Stain S, Beart R, Danenberg P: Quantitation of intratumoral thymidylate synthase expression predicts for resistance to protracted infusion of 5-fluorouracil and weekly leucovorin in disseminated colorectal cancers: preliminary report from an ongoing trial. Eur J Cancer 1995, 3 | A(7-8): | 306- I 310.

18. Aschele C, Lonardi S, Monfardini S: Thymidylate Synthase expression as a predictor of clinical response to fluoropyrimidine-based chemotherapy in advanced colorectal cancer. Cancer Treat Rev 2002, 28(I):27-47.

19. Marsh S, McLeod HL: Thymidylate synthase pharmacogenetics in colorectal cancer. Clinical colorectal cancer 200I, I(3): I75-I 78. discussion 179-181.

20. Shen MR, Jones IM, Mohrenweiser $H$ : Nonconservative amino acid substitution variants exist at polymorphic frequency in DNA repair genes in healthy humans. Cancer Res 1998, 58(4):604-608.

21. Hoffmeyer S, Burk O, von Richter O, Arnold HP, Brockmoller J, Johne A, Cascorbi I, Gerloff T, Roots I, Eichelbaum M, Brinkmann U: Functional polymorphisms of the human multidrug-resistance gene: multiple sequence variations and correlation of one allele with P-glycoprotein expression and activity in vivo. Proc Natl Acad Sci USA 2000, 97(7):3473-3478.

22. Stoehlmacher J, Park DJ, Zhang W, Groshen S, Tsao-Wei DD, Yu MC, Lenz HJ: Association between glutathione S-transferase PI, TI, and MI genetic polymorphism and survival of patients with metastatic colorectal cancer. J Natl Cancer Inst 2002, 94( ( 2 2):936-942

23. Kawakami K, Salonga D, Park JM, Danenberg KD, Uetake $H$ Brabender J, Omura K, Watanabe G, Danenberg PV: Different lengths of a polymorphic repeat sequence in the thymidylate synthase gene affect translational efficiency but not its gene expression. Clin Cancer Res 200I, 7( I 2):4096-4 I0I.

24. International Union Against Cancer. TNM classification of malignant tumors. 6th edition. New York: Wiley-Liss, Inc; 2002.

25. Website title [http://web.umassmed.edu/bioapps/ primer3 www.cgi]

26. van der Logt EM, Bergevoet SM, Roelofs HM, van Hooijdonk Z, te Morsche RH, Wobbes T, de Kok JB, Nagengast FM, Peters WH: Genetic polymorphisms in UDP-glucuronosyltransferases and glutathione S-transferases and colorectal cancer risk. Carcinogenesis 2004, 25( I 2):2407-24I5.

27. Yeh CC, Hsieh LL, Tang R, Chang-Chieh CR, Sung FC: Vegetable/ fruit, smoking, glutathione S-transferase polymorphisms and risk for colorectal cancer in Taiwan. World J Gastroenterol 2005, I I ( I 0): | 473- | 480.

28. Kurzawski M, Drozdzik M, Suchy J, Kurzawski G, Bialecka M, Gornik W, Lubinski ]: Polymorphism in the P-glycoprotein drug transporter MDR I gene in colon cancer patients. Eur J Clin Pharmacol 2005, 6 I (5-6):389-394.

29. Komoto C, Nakamura T, Sakaeda T, Kroetz DL, Yamada T, Omatsu H, Koyama T, Okamura N, Miki I, Tamura T, Aoyama N, Kasuga M, Okumura K: MDRI haplotype frequencies in Japanese and Caucasian, and in Japanese patients with colorectal cancer and esophageal cancer. Drug Metab Pharmacokinet 2006, 2 I (2): I 26-132.

30. Bae SY, Choi SK, Kim KR, Park CS, Lee SK, Roh HK, Shin DW, Pie JE, Woo ZH, Kang JH: Effects of genetic polymorphisms of MDRI, FMO3 and CYPIA2 on susceptibility to colorectal cancer in Koreans. Cancer Sci 2006, 97(8):774-779. 
31. Curtin K, Bigler J, Slattery ML, Caan B, Potter JD, Ulrich CM: MTHFR C677T and AI298C polymorphisms: diet, estrogen, and risk of colon cancer. Cancer Epidemiol Biomarkers Prev 2004, I 3(2):285-292.

32. Yin G, Kono S, Toyomura K, Hagiwara T, Nagano J, Mizoue T, Mibu R, Tanaka M, Kakeji Y, Maehara Y, Okamura T, Ikejiri K, Futami K, Yasunami Y, Maekawa T, Takenaka K, Ichimiya H, Imaizumi N: Methylenetetrahydrofolate reductase C677T and AI298C polymorphisms and colorectal cancer: the Fukuoka Colorectal Cancer Study. Cancer Sci 2004, 95( I I):908-9I3.

33. Kim DH, Ahn YO, Lee BH, Tsuji E, Kiyohara C, Kono S: Methylenetetrahydrofolate reductase polymorphism, alcohol intake, and risks of colon and rectal cancers in Korea. Cancer Lett 2004, 2 I 6(2): 199-205.

34. Kawakami K, Watanabe G: Identification and functional analysis of single nucleotide polymorphism in the tandem repeat sequence of thymidylate synthase gene. Cancer Res 2003, 63( I 8):6004-6007.

35. Marsh S, Collie-Duguid ES, Li T, Liu X, McLeod HL: Ethnic variation in the thymidylate synthase enhancer region polymorphism among Caucasian and Asian populations. Genomics 1999, 58(3):3 $10-3 \mid 2$.

36. Chen J, Hunter DJ, Stampfer MJ, Kyte C, Chan W, Wetmur JG, Mosig $\mathrm{R}$, Selhub J, Ma J: Polymorphism in the thymidylate synthase promoter enhancer region modifies the risk and survival of colorectal cancer. Cancer Epidemiol Biomarkers Prev 2003, I 2(I0):958-962

37. Stoehlmacher J, Park DJ, Zhang W, Yang D, Groshen S, Zahedy S, Lenz HJ: A multivariate analysis of genomic polymorphisms: prediction of clinical outcome to 5-FU/oxaliplatin combination chemotherapy in refractory colorectal cancer. $\mathrm{Br} / \mathrm{Cancer}$ 2004, 9 I(2):344-354.

38. Yeh CC, Sung FC, Tang R, Chang-Chieh CR, Hsieh LL: Polymorphisms of the XRCCI, XRCC3, \& XPD genes, and colorectal cancer risk: a case-control study in Taiwan. BMC Cancer 2005, 5: 12 .

39. Hong YC, Lee KH, Kim WC, Choi SK, Woo ZH, Shin SK, Kim H: Polymorphisms of XRCCI gene, alcohol consumption and colorectal cancer. Int J Cancer 2005, I I 6(3):428-432.

40. Lunn RM, Langlois RG, Hsieh LL, Thompson CL, Bell DA: XRCCI polymorphisms: effects on aflatoxin BI-DNA adducts and glycophorin A variant frequency. Cancer Res 1999 59(I I):2557-256I.

4I. Matullo G, Guarrera S, Carturan S, Peluso M, Malaveille C, Davico L, Piazza $A$, Vineis $P$ : DNA repair gene polymorphisms, bulky DNA adducts in white blood cells and bladder cancer in a case-control study. Int J Cancer 200I, 92(4):562-567.

42. Hou SM, Falt S, Angelini S, Yang K, Nyberg F, Lambert B, Hemminki $\mathrm{K}$ : The XPD variant alleles are associated with increased aromatic DNA adduct level and lung cancer risk. Carcinogenesis 2002, 23(4):599-603.

43. Ankathil R, Jyothish B, Madhavan J, Nair MK: Deficient DNA repair capacity: a predisposing factor and high risk predictive marker in familial colorectal cancer. J Exp Clin Cancer Res 1999, I 8(I):33-37.

44. Raymond E, Faivre S, Woynarowski JM, Chaney SG: Oxaliplatin: mechanism of action and antineoplastic activity. Semin Oncol 1998, 25(2 Suppl 5):4- 12.

45. Shirao K, Hoff PM, Ohtsu A, Loehrer PJ, Hyodo I, Wadler S, Wadleigh RG, O'Dwyer PJ, Muro K, Yamada Y, Boku N, Nagashima F, Abbruzzese JL: Comparison of the efficacy, toxicity, and pharmacokinetics of a uracil/tegafur (UFT) plus oral leucovorin (LV) regimen between Japanese and American patients with advanced colorectal cancer: joint United States and Japan study of UFT/LV. J Clin Oncol 2004, 22(I 7):3466-3474.

46. Charames GS, Bapat B: Genomic instability and cancer. Curr Mol Med 2003, 3(7):589-596.

47. Goode EL, Ulrich CM, Potter JD: Polymorphisms in DNA repair genes and associations with cancer risk. Cancer Epidemiol Biomarkers Prev 2002, I I (I 2): I5 | 3-I530.

48. Benhamou S, Sarasin A: ERCC2/XPD gene polymorphisms and cancer risk. Mutagenesis 2002, I 7(6):463-469.

49. Benhamou S, Sarasin A: ERCC2/XPD gene polymorphisms and lung cancer: a HuGE review. American journal of epidemiology 2005, I 6 I (I): I- |4.
50. Manuguerra $M$, Saletta $F$, Karagas $M R$, Berwick $M$, Veglia F, Vineis $P$, Matullo G: XRCC3 and XPD/ERCC2 single nucleotide polymorphisms and the risk of cancer: a HuGE review. American journal of epidemiology 2006, I 64(4):297-302.

5I. Bigler J, Ulrich CM, Kawashima T, Whitton J, Potter JD: DNA repair polymorphisms and risk of colorectal adenomatous or hyperplastic polyps. Cancer Epidemiol Biomarkers Prev 2005, I 4(I I Pt I):250I-2508

52. Yin J, Vogel U, Ma Y, Qi R, Sun Z, Wang H: A haplotype encompassing the variant allele of DNA repair gene polymorphism ERCC2/XPD Lys75IGIn but not the variant allele of Asp3 I 2Asn is associated with risk of lung cancer in a northeastern Chinese population. Cancer genetics and cytogenetics 2007 , I 75(I):47-5I

53. Sturgis EM, Zheng R, Li L, Castillo EJ, Eicher SA, Chen M, Strom SS, Spitz MR, Wei Q: XPD/ERCC2 polymorphisms and risk of head and neck cancer: a case-control analysis. Carcinogenesis 2000, 2 I ( I 2):22 I9-2223.

54. Qiao Y, Spitz MR, Shen H, Guo Z, Shete S, Hedayati M, Grossman L, Mohrenweiser $\mathrm{H}$, Wei $\mathrm{Q}$ : Modulation of repair of ultraviolet damage in the host-cell reactivation assay by polymorphic XPC and XPD/ERCC2 genotypes. Carcinogenesis 2002 , 23(2):295-299.

55. Matullo G, Palli D, Peluso M, Guarrera S, Carturan S, Celentano E, Krogh V, Munnia A, Tumino R, Polidoro S, Piazza A, Vineis P: XRCCI, XRCC3, XPD gene polymorphisms, smoking and (32)P-DNA adducts in a sample of healthy subjects. Carcinogenesis 200I, 22(9): I437-I445.

56. Matullo G, Peluso M, Polidoro S, Guarrera S, Munnia A, Krogh V, Masala G, Berrino F, Panico S, Tumino R, Vineis P, Palli D: Combination of DNA repair gene single nucleotide polymorphisms and increased levels of DNA adducts in a population-based study. Cancer Epidemiol Biomarkers Prev 2003, I 2(7):674-677.

57. Spitz MR, Wu X, Wang Y, Wang LE, Shete S, Amos Cl, Guo Z, Lei L, Mohrenweiser $H$, Wei $Q$ : Modulation of nucleotide excision repair capacity by XPD polymorphisms in lung cancer patients. Cancer Res 200I, 6 I (4): I354-I357.

58. Qiao Y, Spitz MR, Guo Z, Hadeyati M, Grossman L, Kraemer KH, Wei Q: Rapid assessment of repair of ultraviolet DNA damage with a modified host-cell reactivation assay using a luciferase reporter gene and correlation with polymorphisms of DNA repair genes in normal human lymphocytes. Mutation research 2002, 509(I-2): 165-174.

\section{Pre-publication history}

The pre-publication history for this paper can be accessed here:

http://www.biomedcentral.com/1471-2407/8/50/prepub

Publish with Biomed Central and every scientist can read your work free of charge

"BioMed Central will be the most significant development for disseminating the results of biomedical research in our lifetime. "

Sir Paul Nurse, Cancer Research UK

Your research papers will be:

- available free of charge to the entire biomedical community

- peer reviewed and published immediately upon acceptance

- cited in PubMed and archived on PubMed Central

- yours - you keep the copyright
BioMedcentral 